\title{
Alternative measure of financial development and investment-cash flow sensitivity: evidence from an emerging economy
}

\author{
Gaurav Gupta ${ }^{1 *}$ (1) and Jitendra Mahakud ${ }^{2}$
}

* Correspondence:

gaurav22lbs@gmail.com

${ }^{1}$ VIT Business School, Vellore Institute of Technology, Vellore 632014, India

Full list of author information is available at the end of the article

\begin{abstract}
This study examines the impact of financial development on corporate investment in terms of their influence on financing constraints. This study also tries to find the effect of financial development on the investment-cash flow sensitivity across the size, degree of financial constraints and group affiliation of the firm. This study employs dynamic panel data model or more specifically system generalized method of moments (GMM) estimation technique. The estimation results reveal that cash flow affects the investment decision of the company positively, which implies that Indian firms are financially constrained. Also, we observe that financial development reduces the investment-cash flow sensitivity and the effect of financial development is more prominent for small size and standalone firms. The results are robust across the period and, for both financially constrained and unconstrained firms. This study contributes to the existing literature by analyzing the impact of financial development on the role of cash flow in determining investments undertaken by the Indian firms, which is an unexplored issue from an emerging market perspective.
\end{abstract}

Keywords: Business groups, Cash flow, Corporate investment, Financial constraints, Financial development, Firm size, Generalized method of moments

\section{Introduction}

Pertinent to the pervasive importance of corporate investment in the growth process of the firm, over the years, the research on the identification of the factors affecting the corporate investment has grown by many folds. The Q-model of investment assumes that, in the perfect capital market, the internal and external funds are perfect substitutes and therefore, the investment decision of a firm is solely a function of investment opportunities and invariant to the firms' cash flow. In the imperfect market condition, external funding is more costly than internal financing because of frictions arising from asymmetric information, agency problem and transaction costs. Under such conditions, firms' investments are mostly affected by the availability of internal funds. Fazzari et al. $(1988,2000)$ document that under an imperfect capital market investments carried out by more financially constrained firms are more sensitive to the availability of internal funds even after controlling growth opportunity proxy $(\mathrm{Q})$. The investment-cash flow sensitivity changes with the

(c) The Author(s). 2019 Open Access This article is distributed under the terms of the Creative Commons Attribution 4.0 International License (http://creativecommons.org/licenses/by/4.0/), which permits unrestricted use, distribution, and reproduction in any medium, provided you give appropriate credit to the original author(s) and the source, provide a link to the Creative Commons license, and indicate if changes were made. 
financing constraints. Most of the studies find the same evidence for developed as well as emerging economies (see for example, Kadapakkam et al. 1998; Goergen and Renneboog 2001; Laeven 2003; Bhaduri 2005; Shen and Wang 2005; Ghosh and Ghosh 2006; Degryse and De Jong 2006; Aggarwal and Zong 2006; Cleary et al. 2007). A controversy arises when Kaplan and Zingales $(1997,2000)$ and Cleary (1999) show that least financially constrained U.S. firms also exhibit greater investment-cash flow sensitivity. Later empirical studies argue that the criteria used to classify firms into financially constrained and unconstrained firms like dividend pay-out ratio, debt financing, debt rating etc. are endogenous and these classifying factors are time-variant also. The potential to resolve the controversy lies in the analysis of data whereby researcher can use exogenous criteria.

Over the years, the literature has focussed on the impact of various other exogenous factors such as financial condition, financial market liberalization, corporate governance etc. on the effect of internal cash flow in investment decision of the firms (Koo and Maeng 2005; Francis et al. 2013; Tran and Le 2017). Financial condition is defined as the current state of financial variables that characterize the supply or demand of financial instruments relevant for economic activity (Hatzius et al. 2010). Movements in financial variables, such as interest rates, exchange rates, asset prices, credit demand, and development of financial institutions may indirectly affect firms' investment via their impacts on financing constraints, that is, the sensitivity of investment to internal funds. The sensitivity of investment to cash flow decreases with the financial development because development of the financial system reduces the corporate borrowing constraints and thus, reduces the dependence of investment on internal funds. The previous empirical studies on the impact of financial development in determination of corporate investment use alternative proxies to measure the financial development. All these proxies include domestic bank credit to private sector divided by gross domestic product (Gochoco-Bautista et al. 2014)), ratio of the sum of total market value for bank lending, stock market capitalization and corporate bond market scaled by gross domestic product (Ro et al. 2017), financial condition index constructed from a group of variables such as spread of lending rates over policy rates, real effective exchange rate, growth of stock market and growth of bank credit to private sector (Tran and Le 2017). All these proxies for financial development measure the financial depth only. But financial development is a multidimensional concept as there are many financial institutions (banks, mutual funds, pension funds, insurance companies etc.) and financial markets (stock market, bond market, money market, foreign exchange market etc.) operate in financial system. The diversity of financial system demands to measure the financial development from multiple indicator perspective. Considering the importance of this issue, the International Monetary Fund (IMF) has advocated the construction of financial institution and financial market development indices in terms of the size of financial institutions and markets (financial depth), degree to which individuals can and do use financial services (access), and efficiency of financial intermediaries and markets in intermediating resources and facilitating financial transactions (efficiency). Further, the World Bank has added another dimension into this i.e. stability of financial institutions and markets (stability). The existing empirical studies fail to consider this multidimensional approach to construct the financial development index. This study extends the existing literature considering all the dimensions of financial development (depth, access, efficiency and stability) suggested by World Bank to construct the financial development index for India. 
Additionally, King and Levine (1993) and Loayza and Ranciere (2006) document that debt financing has contributed significantly to the development and growth of an economy. Singh and Faircloth (2005) have observed that financial leverage plays a multidimensional role in determining corporate financial performance, business growth and long term investment. This is perhaps the reason why the trend in resource allocation for the majority of developed and developing countries shows a consistent increase in debt ratios ${ }^{1}$ over time. However, India remains an exception where debt ratios of firms are consistently declining since the economic liberalization in the early 1990s. Further, debt ratios in many other emerging markets are showing an increasing trend (Mitton, 2007). However, institutional deficiencies in form of underdeveloped bond markets were found to be significant in explaining the decline in the debt ratios (Chauhan, 2017). Indian corporate sector is highly dependent on bank financing (average total bank borrowings to total borrowings is around $17 \%)$ as the corporate debt market is not developed in India. The findings of Chauhan (2017) suggest that firms could be credit rationed and hence, losing value on account of such deficiencies in the institution such as bond markets. The changes in the Indian economy and more specifically, various changes in the financial system such as changes in interest rate, availability of more alternative sources of finance and more reliance on bank capital demand a study on the relationship role of financial development on the determination of corporate investment in the context of India during the period of liberalization.

This study focuses on an emerging Indian economy where the regulatory and institutional constraints are different from the other developed countries. Apart from this, there are many changes that have taken place during the recent years both at the macroeconomic level as well as specific sector level. We observe that (i) foreign investment inflows (FII) have increased from Rs. 224.5 billion in the year 2000 to Rs. 2546.53 billion in 2014, (ii) Growth rate of gross domestic product (GDP) has been varying between $3.8 \%$ to $9.6 \%$ during the same period, and (iii) Private capital formation has changed from Rs. 1065. 24 billion in the year 2000 to 9978.16 billion in the year 2014 (Source: RBI, various annual reports and Handbooks of Statistics on Indian Economy). We also observe that short term interest rate (repo rate) has changed frequently, that reached an all-time high of $14.50 \%$ in August of 2000 and a record low of 4.25\% in April of 2009. All these above-mentioned changes may affect the alternative sources of finance for investments and also the average lending rates of the commercial banks and financial institutions. "India is fifteen years ahead of China in economic and financial market reforms. Interest rates in India are market determined with the RBI doing away with ad hoc government funding in the late 1990s. Government borrowing costs are market determined with the government bond yield curve being the benchmark that determines the borrowing costs for state governments, municipal corporations, banks and corporates. Indian government bond market, one of the most liquid in Asia, is well regulated by the RBI and is also fully electronic. The banking system in India is well regulated and banks' reporting standards, reserve ratios and capital adequacy hold the system strong even in the face of adversities such as the global financial market collapse in 2007-08. SEBI as a regulator has come a long way since it was formed in the early 1990s. As a market regulator, it may have had its ups and downs but the laws that govern capital markets are well formed. The regulator has largely been responsible for the transparency in Indian markets. India has largely allowed FIIs to invest in equities and has increased debt investment limits from $\$ 2.5$ billion in 2003 to $\$ 81$ billion as of 2013 . 
FIIs own atleast 48 percent of free float market cap in India as per a Citigroup report. FIIs like India due to its vibrant financial markets".

"India has clocked an average growth rate over 6.75\% since it ushered into the liberalization regime 25 years back. Favourable demographics, rising middle class, growing urbanization, high knowledge-based industries - umpteen arguments have been articulated about why India is the happening place. But these are only the parameters that indicate the attractiveness of the Indian economy; the right lever which is working to make India an attractive and happening place from the perspective of an investor is the gradual reforms process underway. Almost all the sectors of the economyindustrial, financial, agricultural, have been exposed to competitive forces, and in the process have emerged stronger. Though the pace of reforms has been uneven, the process has taken deep enough roots in the political economy to be reversed". ${ }^{3}$

Overall this study examines the role of financial development on corporate investment in terms of their influence on financing constraints and isolated effect of financial development on corporate investment. This study also tries to test whether the effect of financial development on the investment-cash flow sensitivity depends on the period of study, size of the firm, financial constraints and group affiliation of the firm. The data set consists of 617 firms during 1999-2014. We estimate the impact of financial sector development on the investment-cash flow sensitivity by using the system-generalized method of moments (GMM). The major findings of the paper are: (i) Financial development reduces the financial constraints faced by the firm, thereby, declines the investment-cash flow sensitivity and have positive impact on corporate investment. (ii) The effect of the financial development on financial constraints is more (less) during (before) the crisis period and for the firms which pay low (high) dividends and also, the individual effect of financial development is more for low dividend paying firms and during the crisis period. (iii) The effect of the financial development on financial constraints is stronger for smaller and standalone firms than the larger and group affiliated firms and also, financial development have its positive impact on corporate investment across the firm size and ownership style such as group afflation.

The rest of the paper is organized as follows. Section 2 highlights the brief review of literature. Section 3 presents the data and variables. Section 4 presents the models and estimation method. Section 5 discusses the results. The final section provides the conclusions of the study.

\section{Literature review}

The empirical studies on the determination of corporate investment have largely been focused on the firm specific factors. Lamont (1997) has identified that internal funds are accounted for more than three quarters of capital expenditure outlays for the period 1981-1991 for US non-financial corporations. A perfect capital market has free access to external market which leads to the fact that investment decisions will be based on the future profitability and growth opportunities and it does not depend on the internal fund. In an imperfect capital market, the internal and external finances are not perfect substitutes as the presence of information asymmetry cost (Myers and Majluf 1984) and agency cost (Jensen and Meckling 1976) create a wedge between the internal and external funds, making the latter more costly. 
Fazzari et al. (1988) demonstrate that in an imperfect capital market the sensitivity of corporate investment to internal cash flow would be the strongest for firms that faced the greatest wedge between the costs of internal and external funds, i.e. firms that have high financial constraints (firms paying less dividends). This study finds a positive sensitivity of investment to cash flow, even after controlling the growth opportunity proxy Q. A study of Kaplan and Zingales (1997) questioned the interpretation of investment-cash flow sensitivity as a measure of financial constraints. Also, other studies question the interpretation of investment-cash flow sensitivity as an indicator of financial constraints. For example, Kadapakkam et al. (1998) document that investment-cash flow sensitivity was generally highest (smallest) among the larger (smaller) firms. Cleary (1999) also finds that more constrained and less creditworthy firms have smaller investment-cash flow sensitivity. A study conducted by Gomes (2001) document that investment-cash flow sensitivity is theoretically not sufficient for measuring financial constraints. Also, study of Alti (2003) found that new investment is sensitive to cash flow without financing frictions.

The study of Moyen (2004) considers a model with and without financial constraints. Their simulation results showed that investment-cash flow sensitivity is observed in both models. Cleary (2006) documents that firms with a stronger financial position and higher dividend payout have higher investment-cash flow sensitivity than firms with a weaker financial position and lower payout. Cleary et al. (2007) also find that the relationship between investment and cash flow is U-shaped: investment increases monotonically with large internal funds but decreases with low funds. Gatchev et al. (2010) document that investment-cash flow sensitivity does not acknowledge the multifaceted interdependence between financial and investment decisions and provides an incomplete and misleading view of true financial constraints.

Studies conducted by Erickson and Whited (Erickson and Whited 2000; Whited and Erickson 2002) found that mismeasured q leads to an overstated relationship between investment and cash flow, even for financially constrained firms, and that q theory has good explanatory power once purged of measurement error. Alti (2003) also document that $\mathrm{q}$ is a noisy proxy of near-term investment opportunities. Adding to the debate on the interpretation of investment-cash flow sensitivity, its sharp decline in the U.S and other countries, Allayannis and Mozumdar (2004) recorded a decline in investment-cash flow sensitivity over the period from 1977 to 1996, particularly for the most constrained firms. Ağca and Mozumdar (2008) suggested that investment-cash flow sensitivity decreases with factors that reduce capital market imperfections. Islam and Mozumdar (2007) found a negative relationship between cross-country financial development and the importance of internal capital for investment decisions. Brown and Petersen (2009) examined the changes in investment-cash flow sensitivity over the period from 1970 to 2006. Their study argues that the decline can be attributed to the changing composition of investment from physical investment to $R \& D$ and the rising importance of public equity.

More recently, a study conducted by Chen and Chen (2012) made the observation that investment-cash flow sesntivity has declined and disappeared during the 2007-2009 credit crunch. Moshirian et al. (2017) find that changes in asset composition (from tangible to intangible productive capital) play an important role in explaining the fading of investment-cash flow sensitivity over time. Specifically, lower intensity of physical 
investment in developed countries over time explains the cross-country variation in the sensitivity as well as the time trend.

Several empirical studies of the investment-cash flow sensitivity show their strong support towards the findings of Fazzari et al. (1988). These studies have classified the sample in different sub-samples with different degrees of financial constraints based on certain parameters such as group affiliation (Hoshi et al. 1991), bond rating (Gilchrist and Himmelberg 1995), size of the firm (Audretsch and Elston 2002), leverage (Calomiris et al. 1994; Aivazian et al. 2005; Ahn et al. 2006), investor horizon (Attig et al. 2012), information asymmetry (Ascioglu et al. 2008) and find the evidence that internal cash flow has a positive impact on investments undertaken by the firm and the impact is more for the more financially constrained firms than the less financially constrained firms. Love (2003) uses an Euler equation approach and confirms that firms in less developed countries show a greater sensitivity of investment to cash stock.

The studies of Kadapakkam et al. (1998) and Cleary (2006) also, find that in several developed countries investment is more sensitive to cash flow for firms that are a priori expected to be less financially constrained. Shin and Park (1999) also find that more constrained firms have higher sensitivity of firm investment to internal funds for the Korean companies and Caggese (2007) finds the similar results in the context of UK companies. These studies conclude that internal liquidity of the firm is a significant determinant of corporate investment for the financially constrained firms and investment-cash flow sensitivity can also be used as a useful measure of financial constraints. On the other side, Kaplan and Zingales (1997) and Cleary (1999) have shown that sensitivity of firms is more for the least financial constrained firms.

George et al. (2011) find strong investment-cash flow sensitivity for both group affiliated and independent firms in India. This study also suggests that investment-cash flow sensitivity of group affiliated firms is not significantly lower than the unaffiliated firms. Considering the data from the Euro zone Pindado et al. (2011) suggest that the investment cash flow sensitivity is lower for the family owned firms. Gochoco-Bautista et al. (2014) find that financial conditions affect firms' growth opportunities and investment demand, financial development primarily affects firms' external financing constraints and large firms benefit more from improved financial conditions, while small firms benefit more from financial development. Ro et al. (2017) also find that financial development affects a firm's investment by reducing the firm's financial restrictions in Korea and the effects of financial development on a firm's financial restrictions are varied by industry, firm size and financial crisis.

Further, the empirical studies investigate the investment-cash flow sensitivity hypothesis considering various other factors like size and age of the company, nature of affiliation of the company, financial markets liberalization, financial market development, financial condition of the market, corporate governance, labour unions etc. Devereux and Schiantarelli (1990) and Schaller (1993) find that cash flow effects are important for smaller and young firms. Houston and James (1996) find that investment-cash flow sensitivity is higher for firms that are closely tied to a single bank than the firms that have relationship with several banks. Firms that hedge their financial risk with derivatives and foreign currency debt are able to reduce their financial constraints, which further decline the investment-cash flow sensitivity (Froot et al. 1993; Geczy et al. 1997; Allayannis and Mozumdar 2000; Kedia and Mozumdar 2001). Koo and Maeng (2005) find that financial 
market liberalization decreases the effect of internal cash flow on investment for the Korean firms and this effect is more pronounced for the large and Chaebol affiliated firms.

Francis et al. (2013) find that better corporate governance lowers the dependence of emerging market firm's investment on internally generated cash flows. This study also suggests the substitutability between firm-specific and country level governance in determining the firms' investment sensitivity to internal cash flow. Using a Q-model of investment Chen and Chen (2013) find that the capital expenditure of firms are 1.71 times more sensitive to internal cash flow when unionization rates increase one standard deviation from the mean. This study suggests that higher investment-cash flow sensitivity in unionized firms is primarily driven by the incentive of these firms to reduce liquidity and enhance bargaining power against the union. Financial development and financial condition of the market also reduce the investment-cash flow sensitivity in Asian emerging markets and the degree of sensitivity varies across the size of the firm (Gochoco-Bautista et al. 2014). Andrén and Jankensgård (2015) find that when excess liquidity or availability of capital becomes abundant, the investment-cash flow sensitivity decreases for financially constrained firms and increases for unconstrained firms suggesting the fact that the relationship is driven by the agency problems related to free cash flow. Chowdhury et al. (2016) show that information asymmetry decreases following Sarbanes-Oxley Act and there is a decrease in the investment cash-flow sensitivity pre to post Sarbanes-Oxley Act. Analysing the data of the Vietnamese listed firms, Tran and Le (2017) find that financial conditions of the market affect investment behaviour only for the firms with negative cash flows, which implies that better financial conditions alleviate the financing constraints and also the sensitivity of investment to negative cash flow. This study also suggests that this effect is greater for larger firms and firms without state ownership.

In a nutshell, it is observed that the investment-cash flow sensitivity hypothesis has been investigated all over the world from time to time. Most of the studies have shown their support to findings of Fazzari et al. (1988) and this hypothesis has been reinvestigated again and again considering the impact of various exogenous factors like corporate governance, financial market condition, and financial liberalization etc. on the role of internal cash flow in determining the corporate investment. However, the studies on impact of financial development on investment-cash flow sensitivity are few and the measures of financial development capture only one dimension of development i.e. depth. This study tries to overcome this research gap by analysing the effect of financial development, which captures all four dimensions of development i.e. depth, access, efficiency and stability on investment-cash flow sensitivity of the Indian listed companies. This study provides out-of-sample evidence from an emerging market perspective.

\section{Data and variables}

Our data targets all the manufacturing firm data available in the prowess database maintained by Center for Monitoring Indian Economy (CMIE). We find 1922 companies which have continues fixed investment data during the study period i.e. 1999-2000 to 2013-14. Out of 1922 firms 1246 firms don't have the adequate data for other major explanatory variables. Further following Jangili and Kumar (2010), we have not considered 18 Private firms as private firms do not disclose their financial statement. Finally, we 
selected 617 firms which have continuous data throughout the period. The variables used to construct financial development index are collected from World Bank Development Indicators (World Bank) data base. Table 1 shows the variables used in this paper. All continuous variables are winsorized at their 1st and 99th percentile.

We divide the sample according to crises period, dividend payout ratio, size and group affiliation to test the difference in the effect of financial development on the investment cash flow sensitivity. We divide our data into two sub-periods, i.e., data period without any major crisis (1999-2000 to 2006-2007) and the remaining period (2007-2008 to 20132014) which has witnessed the series of crises such as global financial crisis (2007-08), the European sovereign debt crisis (2010) and the Russian financial crisis (2014), and carryout our analysis.

\section{Measuring financial development index}

As suggested by World Bank we construct a multidimensional financial development index for India. According to IMF [Source: Svirydzenka 2016] and World Bank, financial development is defined as a combination of depth (size and liquidity of markets), access (ability of individuals and companies to access financial services), efficiency (ability of institutions to provide financial services at low cost and with sustainable revenues, and the level of activity of capital markets) and stability (stability of financial institutions and markets). Following the procedure provided in OECD Handbook on Constructing Composite Indicators [Source: (OECD, 2008)] the financial development index for India has been constructed. This broad multi-dimensional approach to defining financial development follows the following matrix (Fig. 1) of financial system characteristics:

Following the approach followed by Svirydzenka (2016) first, starting from the bottom of the pyramid in Fig. 1, eight lower level sub-indices are constructed using a list of indicators to measure how deep, accessible, efficient and stable financial institutions and

Table 1 Variables descriptions

\begin{tabular}{|c|c|}
\hline $\begin{array}{l}\text { Abbreviation } \\
\text { (1) }\end{array}$ & $\begin{array}{l}\text { Description } \\
(2)\end{array}$ \\
\hline $\bar{K}$ it & Capital at the beginning of period $t$ (fixed assets at the end of the period $t-1$ ) \\
\hline$l_{\text {it }}$ & Investment during period $\mathrm{t}\left(K_{t+1}+D E P R_{t}-K_{t}\right)$ \\
\hline$D E P R_{i t}$ & Depreciation during period $t$ \\
\hline$Q_{i t}$ & Average $\mathrm{Q}$ at the beginning of period $\mathrm{t}$ \\
\hline$B_{i t}$ & Book value of debt at the beginning period $t$ \\
\hline$E_{i t}$ & Market value of equity at the beginning period $t$ \\
\hline$T A_{i t}$ & Total assets at the beginning of period of $t$ \\
\hline$C F_{i t}$ & Cash flow during the period $t$ (Net profit after tax + depreciation during $\mathrm{t}-1$ ) \\
\hline$S_{i t}$ & Sales during the period $t$ \\
\hline$F D I_{t}$ & Financial development index during the period t \\
\hline$B / G_{i}$ & 1 for larger firms, = 0 for small firms \\
\hline$S M A L L_{i}$ & 1 for small firms, $=0$ for large firms \\
\hline STAND $_{i}$ & 1 for standalone firms, 0 for group affiliated firms \\
\hline GROUP & 1 for group affiliated firms, 0 for standalone firms \\
\hline
\end{tabular}




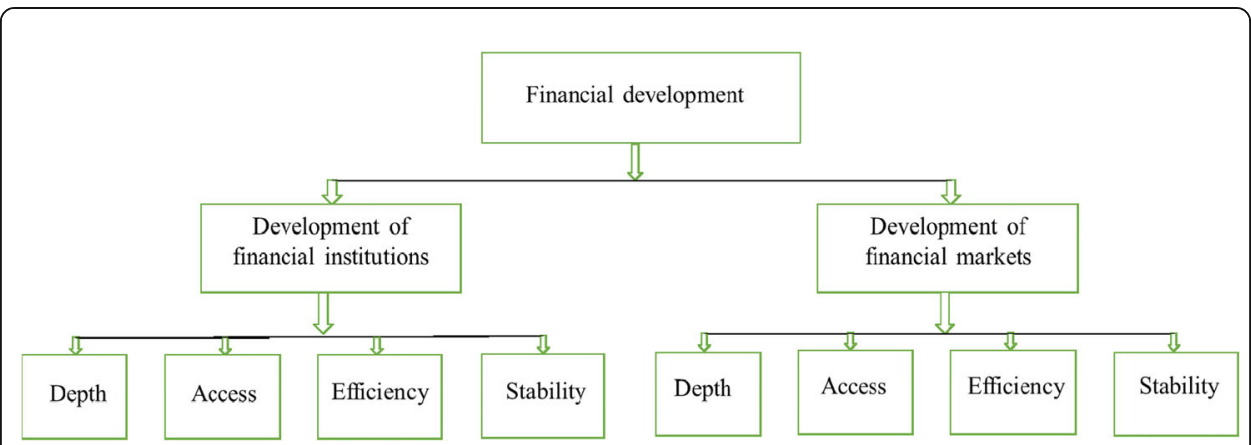

Fig. 1 Financial development index pyramid. Following the approach followed by Svirydzenka (2016) first, starting from the bottom of the pyramid in Fig. 1, eight lower level sub-indices are constructed using a list of indicators to measure how deep, accessible, efficient and stable financial institutions and financial markets are. These sub-indices are aggregated into two higher level sub-indices, which measure how developed financial institutions and financial markets are overall. Finally, these two sub-indices are aggregated into the overall measure of financial development index

financial markets are. These sub-indices are aggregated into two higher level sub-indices, which measure how developed financial institutions and financial markets are overall. Finally, these two sub-indices are aggregated into the overall measure of financial development index. Table 2 presents the set of key indicators chosen to capture the different aspects of the financial system characteristics. Those variables are selected, which are available across the study period.

Following steps are followed to construct the index:

(i) Each series is winsorized to prevent extreme values from distorting the $0-1$ indicators.

(ii) Winsorized indicators are then normalized between 0 and 1, using the min-max procedures $^{4}$ to facilitate aggregation over variables expressed in different measurement units.

Table 2 Variables used for construction of financial development index

\begin{tabular}{|c|c|c|}
\hline \multirow[t]{2}{*}{ Category } & \multicolumn{2}{|l|}{ Indicator } \\
\hline & Financial Institutions & Financial Markets \\
\hline Depth & $\begin{array}{l}\text { Private sector credit to GDP } \\
\text { Mutual fund assets to GDP } \\
\text { Pension fund assets to GDP } \\
\text { Nonbank financial assets to GDP }\end{array}$ & $\begin{array}{l}\text { Stock market capitalization to GDP } \\
\text { Stock market total value traded to GDP } \\
\text { International debt issues to GDP } \\
\text { Outstanding domestic private debt securities to GDP } \\
\text { Outstanding domestic public debt securities to GDP }\end{array}$ \\
\hline Access & $\begin{array}{l}\text { Bank branches per } 100,000 \text { adults } \\
\text { ATMs per 100,000 adults } \\
\text { Working capital financed by banks }\end{array}$ & $\begin{array}{l}\text { Market capitalization excluding } 10 \text { top largest companies } \\
\text { to total market capitalization } \\
\text { Non-financial corporate bonds to total bonds } \\
\text { Investments financed by equity or stock sales }\end{array}$ \\
\hline Efficiency & $\begin{array}{l}\text { Bank net interest margin } \\
\text { Bank lending-deposit spread } \\
\text { Non-investment income to total income } \\
\text { Return on assets } \\
\text { Return on equity } \\
\text { Bank cost to income ratio } \\
\text { Bank overhead cost to total assets }\end{array}$ & $\begin{array}{l}\text { Stock market turnover ratio (stocks traded to } \\
\text { capitalization) }\end{array}$ \\
\hline Stability & $\begin{array}{l}\text { Bank Z-score } \\
\text { Non-performing loans to total loans (\%) } \\
\text { Bank credit to bank deposits } \\
\text { Capital to risk weighted assets }\end{array}$ & Stock price volatility \\
\hline
\end{tabular}


(iii) Indicators are then aggregated into eight sub-indices at the bottom of the pyramid in Fig. 1. The aggregation is a weighted linear average of the underlying series, where the weights are obtained from principal component analysis, ${ }^{5}$ reflecting the contribution of each underlying series to the variation in the specific sub-index. The factor loadings on the first principal component are chosen as weights as it explains more than $60 \%$ of the variance. Table 3 shows the principal component analysis results.

(iv) All of the sub-indices are then re-normalized using the min-max procedure, to keep the range between 0 and 1 .

(v) Sub-indices are aggregated into higher-level indices using the same procedure as above (points I to III) to construct the aggregate financial development index (FDI). The FDI is again renormalized to keep the range between 0 and 1 .

Also, we separated our whole sample into two sub-samples such as low dividend pay-out ratio firms and high dividend pay-out ratio firms. Further, Following Lin et al. (2012) and Kadapakkam et al. (1998), we divided all total assets value (market capitalization) in three sub-sample such as top, middle and bottom sample based on the tercile approach. A large size dummy variable BIG takes the value 1 if the value of total assets comes in the top sample (upper tercile) and zero otherwise. Similarly we use a dummy variable 1 for construct a small size dummy variable SMALL which indicates that total assets value comes in the bottom sample (lower tercile) and zero otherwise. The total assets value come under the middle sample (middle tercile) considered as medium size firms. The firm's affiliation to any group is represented as a dummy variable GROUP and take value 1 and the remaining firms as STAND and take value zero. The firm's which are not affiliated to any group represented as a dummy variable STAND and takes value 1 and the remaining firms as GROUP and take value zero.

Table 4 presents the summary statistics (mean and standard deviation) of investment to capital ratio, sales to capital ratio, cash flow and $Q$ ratio. This table showing the behavior of these ratio across the nature of firms and period such as business group affiliation, frim size and crisis period. Large, group affiliated and high dividend paying firms have higher investment to capital ratio than small, standalone or independent and low dividend paying firms. Large, group affiliated and high dividend paying firms appear to hold more internal cash flow relative to capital than the small, standalone and low dividend paying firms. Also, sales to capital ratio for small, standalone and low

Table 3 Share of variance explained by PCA components

\begin{tabular}{|c|c|c|c|c|c|c|c|c|c|c|c|}
\hline & \multicolumn{4}{|c|}{ Financial Institutions (FI) } & \multicolumn{4}{|c|}{ Financial Markets (FM) } & \multicolumn{3}{|c|}{ Sub-Indices } \\
\hline & Depth & Access & Efficiency & Stability & Depth & Access & Efficiency & Stability & $\mathrm{Fl}$ & FM & $\mathrm{FD}$ \\
\hline$\overline{P C_{1}}$ & 0.67 & 0.78 & 0.51 & 0.63 & 0.57 & 0.65 & - & - & 0.63 & 0.71 & 0.81 \\
\hline $\mathrm{PC}_{2}$ & 0.17 & 0.20 & 0.21 & 0.19 & 0.21 & 0.19 & - & - & 0.17 & 0.14 & 0.19 \\
\hline $\mathrm{PC}_{3}$ & 0.11 & 0.12 & 0.11 & 0.12 & 0.11 & 0.09 & - & - & 0.12 & 0.09 & - \\
\hline $\mathrm{PC}_{4}$ & 0.05 & - & 0.08 & 0.06 & 0.08 & 0.07 & - & - & 0.08 & 0.06 & - \\
\hline $\mathrm{PC}_{5}$ & - & - & 0.05 & - & 0.03 & - & - & - & - & - & - \\
\hline $\mathrm{PC}_{6}$ & - & - & 0.03 & - & - & - & - & - & - & - & - \\
\hline $\mathrm{PC}_{7}$ & - & - & 0.01 & - & - & - & - & - & - & - & \\
\hline
\end{tabular}

Source: Authors' own estimation 
Table 4 Summary statistics of the key variables

\begin{tabular}{llllll}
\hline Firms/Periods & $I / K$ & $C F / K$ & $Q$ & $S / K$ & $\begin{array}{l}\text { No. } \\
\text { of } \\
\text { firms }\end{array}$ \\
& $\begin{array}{l}\text { Mean (Std.) } \\
(1)\end{array}$ & $\begin{array}{l}\text { Mean (Std.) } \\
(2)\end{array}$ & $\begin{array}{l}\text { Mean (Std.) } \\
(3)\end{array}$ & $\begin{array}{l}\text { Mean (Std.) } \\
(4)\end{array}$ & $\frac{15)}{(5)}$ \\
\hline All firms & $0.19(0.23)$ & $0.16(0.47)$ & $1.12(0.74)$ & $0.20(0.49)$ & 617 \\
Large firms & $0.22(0.37)$ & $0.19(0.43)$ & $1.36(0.81)$ & $0.22(0.45)$ & 146 \\
Small firms & $0.14(0.42)$ & $0.13(0.47)$ & $1.02(0.65)$ & $0.18(0.58)$ & 335 \\
Standalone firms & $0.18(0.26)$ & $0.14(0.45)$ & $1.45(0.68)$ & $0.16(0.38)$ & 220 \\
Group affiliated firms & $0.23(0.21)$ & $0.17(0.52)$ & $1.10(0.76)$ & $0.24(0.46)$ & 397 \\
High dividend paying firms & $0.23(0.41)$ & $0.21(0.32)$ & $1.34(0.55)$ & $0.22(0.36)$ & 233 \\
Low dividend paying firms & $0.17(0.33)$ & $0.15(0.38)$ & $1.15(0.63)$ & $0.14(0.42)$ & 384 \\
Before crisis period & $0.23(0.31)$ & $0.17(0.35)$ & $1.41(0.68)$ & $0.21(0.29)$ & 617 \\
During crisis period & $0.21(0.49)$ & $0.11(0.41)$ & $0.98(0.83)$ & $0.19(0.42)$ & 617 \\
\hline Soure: Prows
\end{tabular}

Source: Prowess database. Source: Author's own Calculation

dividend paying firms are higher than the large, group affiliated and high dividend paying firms. The Q-ratio is more for large, group affiliated and high dividend paying firms. Our summary statistics also reveal that investment to capital ratio, sales to capital ratio, cash flow and Q are high before the crisis period than during the crisis period.

Table 5 presents the correlation matrix of the key variables used in this study. The correlation coefficient of 0.671 among $I / K$ and $C F / K$ confirm that there has been a positive relationship between investment and internal cash flow. We also find that positive association among investment to capital ratio and other independent variables used in this study such as Tobin's Q and sales to capital ratio. Insignificant and lesser correlation among the explanatory variables rules out the problem of multicollinearity in the estimation process. The VIF test results also confirm the lesser multicollinearity problem in this case.

\section{Models and estimation methods}

Investment models

Following Love (2003), Laeven (2003) and Ratti et al. (2008) this paper adopts both Q-model and Euler model of investment.

Table 5 Correlation matrix of the key variables

Note: (i) * show the $10 \%$ level of significance respectively 


\section{Q-model}

In the Q-model each firm is assumed to maximise its present value subject to the capital accumulation constraint. The final equation of the Q-model is specified as:

The final equation of the Q-model is specified as:

$$
(I / K)_{i t}=\alpha+\beta_{1}(I / K)_{i t-1}+\beta_{2} Q_{i t}+\vartheta_{i}+\lambda_{t}+\mu_{i t}
$$

Where, $I=$ net investment, $K=$ capital stock at the beginning of the period, $Q=Q$-ratio. $\vartheta_{i}$ is the firm specific effects, $\lambda_{t}$ is the time specific effect, $\mu_{i t}$ is white noise. The subscripts $i$, and $t$, represent the firms' and time respectively. According to the Q-model financial factors do not affect investment, only $Q$ is the sole determinant of investment.

Further, we include another term measuring financial condition of the firm to eq. (1) in order to test the impact of financial constraints on investment. The equation becomes:

$$
(I / K)_{i t}=\alpha+\beta_{1}(I / K)_{i t-1}+\beta_{2} Q_{i t}+\beta_{3}(C F / K)_{i t}+\vartheta_{i}+\lambda_{t}+\mu_{i t}
$$

Here, $C F$ is the internal cash flow of the firm.

Our paper examines the role of financial development on corporate investment in terms of their influence on financing constraints. We assume that as financial development has direct impact on the cost of external finance the state of the financial development may change the role of internal liquidity condition of the firm in determining the corporate investment. Considering the neoclassical model of investment and the effect of financial development on investment-cash flow sensitivity, the model is specified as follows:

$$
\begin{aligned}
(I / K)_{i t}= & \alpha+\beta_{1}(I / K)_{i t-1}+\beta_{2} Q_{i t}+\beta_{3}\left(C F /{ }_{K}\right)_{i t}+\beta_{4}(C F / K)_{i t} \times F D I_{t} \\
& +\vartheta_{i}+\lambda_{t}+\mu_{i t}
\end{aligned}
$$

Here, FDI is the financial development index.

The interaction term in eq. (3) captures the effect of financial development on the sensitivity of investment to internal funds. We expect that $\beta_{3}>0$ as an increase in cash flow leads to an increase in the level of investment expenditure or cash flow does not affects firm's investment (i.e. $\beta_{3}=0$ ). The primary hypothesis of this paper is that the sensitivity of investment to cash flow decreases with the financial development because developments in the financial system reduce the corporate borrowing constraints and thus, reduce the dependence of investment on internal funds. Therefore, we expect that $\beta_{4}<0$.

Further, we modify eq. (3) by incorporating a direct impact of financial development on corporate investment and the model is specified as follows:

$$
\begin{aligned}
(I / K)_{i t}= & \alpha+\beta_{1}(I / K)_{i t-1}+\beta_{2} Q_{i t}+\beta_{3}\left(C F /{ }_{K}\right)_{i t}+\beta_{4}\left(C F / /_{K}\right)_{i t} \times F D I_{t} \\
& +\beta_{5} F D I_{t}+\vartheta_{i}+\lambda_{t}+\mu_{i t}
\end{aligned}
$$

Further, we try to test whether the effect of financial development on the investment cash flow sensitivity depends on the size of the firm by estimating the following equation:

$$
\begin{aligned}
(I / K)_{i t}=\alpha & +\beta_{1}(I / K)_{i t-1}+\beta_{2} Q_{i t}+\beta_{3}\left(C F /{ }_{K}\right)_{i t}+\beta_{4}(C F / K)_{i t} \times B I G_{i} \\
& \times F D I_{t}+\beta_{5}\left(C F /{ }_{K}\right)_{i t} \times S M A L L_{i} \times F D I_{t}+\vartheta_{i}+\lambda_{t}+\mu_{i t}
\end{aligned}
$$


Where, $B I G$ is a dummy variable whose value is 1 for big firms and zero otherwise. Similarly, the value of SMALL is one for small firms and 0 otherwise. We expect that $\beta_{3}>0, \beta_{4}<0$ and $\beta_{5}<0$. Comparing the abslute value of $\beta_{4}$ and $\beta_{5}$ we examine whether the effect of financial development is stronger for big firms or small firms.

Next, as business group affiliation is a very important issue in the context of Indian corporate sector we estimate another equation specified below to investigate whether affiliation to a business group affects the impact of financial development on the investment-cash flow sensitivity.

$$
\begin{aligned}
(I / K)_{i t}=\alpha & +\beta_{1}(I / K)_{i t-1}+\beta_{2} Q_{i t}+\beta_{3}\left(C F /{ }_{K}\right)_{i t}+\beta_{4}\left(C F /{ }_{K}\right)_{i t} \times \operatorname{STAND}_{i} \\
& \times F D I_{t}+\beta_{5}\left(C F /{ }_{K}\right)_{i t} \times \operatorname{GROUP}_{i} \times F D I_{t}+\vartheta_{i}+\lambda_{t}+\mu_{i t}
\end{aligned}
$$

Where, STAND is a dummy variable whose value is 1 for standalone companies and zero otherwise. Similarly GROUP is a dummy whose value is 1 for group affiliated firms and zero otherwise. We can examine the relative influence of financial development on the investment-cash flow sensitivity of the standalone and group affiliated firms.

Further, we modify eqs. (5) and (6) by incorporating a direct impact of financial development on corporate investment. These models are specified as follows:

$$
\begin{aligned}
(I / K)_{i t}=\alpha & +\beta_{1}(I / K)_{i t-1}+\beta_{2} Q_{i t}+\beta_{3}(C F / K)_{i t}+\beta_{4}(C F / K)_{i t} \times B I G_{i} \\
& \times F D I_{t}+\beta_{5}(C F / K)_{i t} \times S M A L L_{i} \times F D I_{t}+\beta_{6} F D I_{t}+\vartheta_{i}+\lambda_{t}+\mu_{i t} \\
(I / K)_{i t}=\alpha+ & \beta_{1}(I / K)_{i t-1}+\beta_{2} Q_{i t}+\beta_{3}(C F / K)_{i t}+\beta_{4}(C F / K)_{i t} \times S T A N D_{i} \\
& \times F D I_{t}+\beta_{5}\left(C F /{ }_{K}\right)_{i t} \times G R O U P_{i} \times F D I_{t}+\beta_{6} F D I_{t}+\vartheta_{i}+\lambda_{t}+\mu_{i t}
\end{aligned}
$$

\section{Euler's equation}

Further, considering the certain limitation of Q-model of investment a number of studies estimate the Euler equation, which is obtained by rearranging first order conditions to the problem of firm value optimization under an imperfect capital market.

The Euler equation in the linear form is specified as:

$$
(I / K)_{i t}=\alpha+\beta_{1}(I / K)_{i t-1}+\beta_{2}(S / K)_{i t}+\beta_{3}(C F / K)_{i t}+\vartheta_{i}+\lambda_{t}+\mu_{i t}
$$

Where $S=$ net sales.

Considering the effect of financial development on investment-cash flow sensitivity, the model is specified as follows: 


$$
\begin{aligned}
(I / K)_{i t}=\alpha & +\beta_{1}(I / K)_{i t-1}+\beta_{2}(S / K)_{i t}+\beta_{3}(C F / K)_{i t}+\beta_{4}(C F / K)_{i t} \\
& \times F D I_{t}+\vartheta_{i}+\lambda_{t}+\mu_{i t}
\end{aligned}
$$

We expect that $\beta_{3}>0$, and $\beta_{4}<0$.

Considering the direct effect of financial development on corporate investment, the model is specified as follows:

$$
\begin{aligned}
(I / K)_{i t}=\alpha & +\beta_{1}(I / K)_{i t-1}+\beta_{2}(S / K)_{i t}+\beta_{3}(C F / K)_{i t}+\beta_{4}(C F / K)_{\mathrm{i} t} \\
& \times F D I_{t}+\beta_{5} F D I_{t}+\vartheta_{i}+\lambda_{t}+\mu_{i t}
\end{aligned}
$$

Further considering the effect of firm size and group affiliation on investment-cash flow sensitivity and also, the individual effect of financial development on corporate investment in the Euler's equation we specify following four eqs. (12), (13), (14) and (15).

$$
\begin{aligned}
& (I / K)_{i t}=\alpha+\beta_{1}(I / K)_{i t-1}+\beta_{2}(S / K)_{i t}+\beta_{3}(C F / K)_{i t}+\beta_{4}(C F / K)_{i t} \\
& \times B I G_{i} \times F D I_{t}+\beta_{5}\left(C F /{ }_{K}\right)_{i t} \times S M A L L_{i} \times F D I_{t}+\vartheta_{i}+\lambda_{t}+\mu_{i t} \\
& (I / K)_{i t}=\alpha+\beta_{1}(I / K)_{i t-1}+\beta_{2}(S / K)_{i t}+\beta_{3}(C F / K)_{i t}+\beta_{4}(C F / K)_{i t} \\
& \times \operatorname{STAND}_{i} \times F D I_{t}+\beta_{5}\left(C F /{ }_{K}\right)_{i t} \times \operatorname{GROUP}_{i} \times F D I_{t}+\vartheta_{i}+\lambda_{t}+\mu_{i t}
\end{aligned}
$$

Comparing the absolute values of the coefficients $\beta_{4}$ and $\beta_{5}$ in the eqs. (12) and (13) we can test which firm are more strongly affected by the financial development.

$$
\begin{aligned}
(I / K)_{i t}=\alpha & \beta_{1}(I / K)_{i t-1}+\beta_{2}(S / K)_{i t}+\beta_{3}(C F / K)_{i t}+\beta_{4}(C F / K)_{i t} \\
& \times B I G_{i} \times F D I_{t}+\beta_{5}(C F / K)_{i t} \times S M A L L_{i} \times F D I_{t}+\beta_{6} F D I_{t} \\
& +9_{i}+\lambda_{t}+\mu_{i t} \\
(I / K)_{i t}=\alpha & \beta_{1}(I / K)_{i t-1}+\beta_{2}(S / K)_{i t}+\beta_{3}(C F / K)_{i t}+\beta_{4}(C F / K)_{\mathrm{i} t} \\
& \times S T A N D_{i} \times F D I_{t}+\beta_{5}(C F / K)_{i t} \times G R O U P_{i} \times F D I_{t}+\beta_{6} F D I_{t} \\
& +9_{i}+\lambda_{t}+\mu_{i t}
\end{aligned}
$$

\section{Estimation method}

The dynamic investment models specified in eqs. $(1,2,3,4,5,6,7,8,9,10,11,12,13$, 14 and 15) are likely to suffer from both endogeneity and heterogeneity problems. The explanatory variables in the investment function may be correlated with the error term. Further, the potential correlation of $(I / K)_{i t-1}$ with the fixed effects $\left(\vartheta_{i}\right.$ and $\left.\lambda_{t}\right)$ also leads to dynamic panel bias (Nickell 1981). The presence of lagged investment to 
capital ratio as an explanatory variable may provide bias estimate from the ordinary least square estimation. Substantial difference across firms in their investment behaviour may also result in a heterogeneity problem. Assuming the presence of unobserved fixed effects we transform over data by applying the forward orthogonal deviation (FOD) transformation proposed by Arellano and Bover (1995), which uses forward mean differencing to transform time series in the dataset. We use a system generalised method of moments (GMM) estimator proposed by Arellano and Bover (1995) and augmented by Blundell and Bond (1998). The system GMM estimator uses lagged level variables as instrument for the differenced equation and lagged differenced variable as instruments for the level equation. We estimate all these equations via two step system GMM with instruments including lagged values of all the variables on the right hand side of the equation. For the post estimation tests we apply the Arellano-Bond test for autocorrelation of the disturbance term $\mu_{i t}$ and Sargan and Hansen tests of over identifying restrictions (i.e. test for joint validity of the instruments). We report test statistics for both the Sargan and Hansen tests because there is a trade-off between their robustness and consistency because of the effects of instrument proliferation. Wald test is used to test the joint significance of the estimated coefficients for all the variables.

\section{Discussion of results}

\section{Baseline results}

Columns ( 1 and 3 ) and (2 and 4) in the Table 6 provide the GMM estimation results of both investment function (Q-model and Euler equation) for the whole sample period. Following the Lensink et al. (2003) we use the $p$-values of $m_{1}$ and $m_{2}$ test statistics which indicates that very little unobserved firm specific effects exist in the estimation results. The consistency of the estimates also depends on the absence of serial correlation (M1 and M2 in the table) in the error terms. We display tests for first-order and second-order serial correlation related to the estimated residuals in the first differences. The null hypothesis here relates to "insignificance" so that a low $P$-value for the test on first-order serial correlation and a high P-value for the test on second-order serial correlation suggests that the disturbances are not serially correlated. The test statistics are asymptotically distributed as standard normal variables. The Sargan and Hansen tests for over-identifying restrictions results show that validity of instruments used for regressions is not rejected and conclude that the instruments used in the estimation are valid. The Wald test results confirm the significance of explanatory variables in explaining the dependent variable. The significant positive coefficient of lagged investment to capital ratio implies that current investment depends on past investment (i.e. there has been a persistence effect in firms' investment undertaken). This positive effect is consistent with the findings in Laeven (2003), Love (2003), Ratti et al. (2008), Firth et al. (2012) and Tran and Le (2017), but inconsistent with the evidence shown by Guariglia (2008) and Gochoco-Bautista et al. (2014). Tobin's Q plays the significant role of increasing the investment-capital ratio as predicted by the theory. The significant positive coefficient of cash flow found from our estimation results in both the investments models implies the presence of financing constraints for Indian firms. With a significant regression coefficient of 0.128 , sales also have a strong explanatory power for firm investment behaviour. 


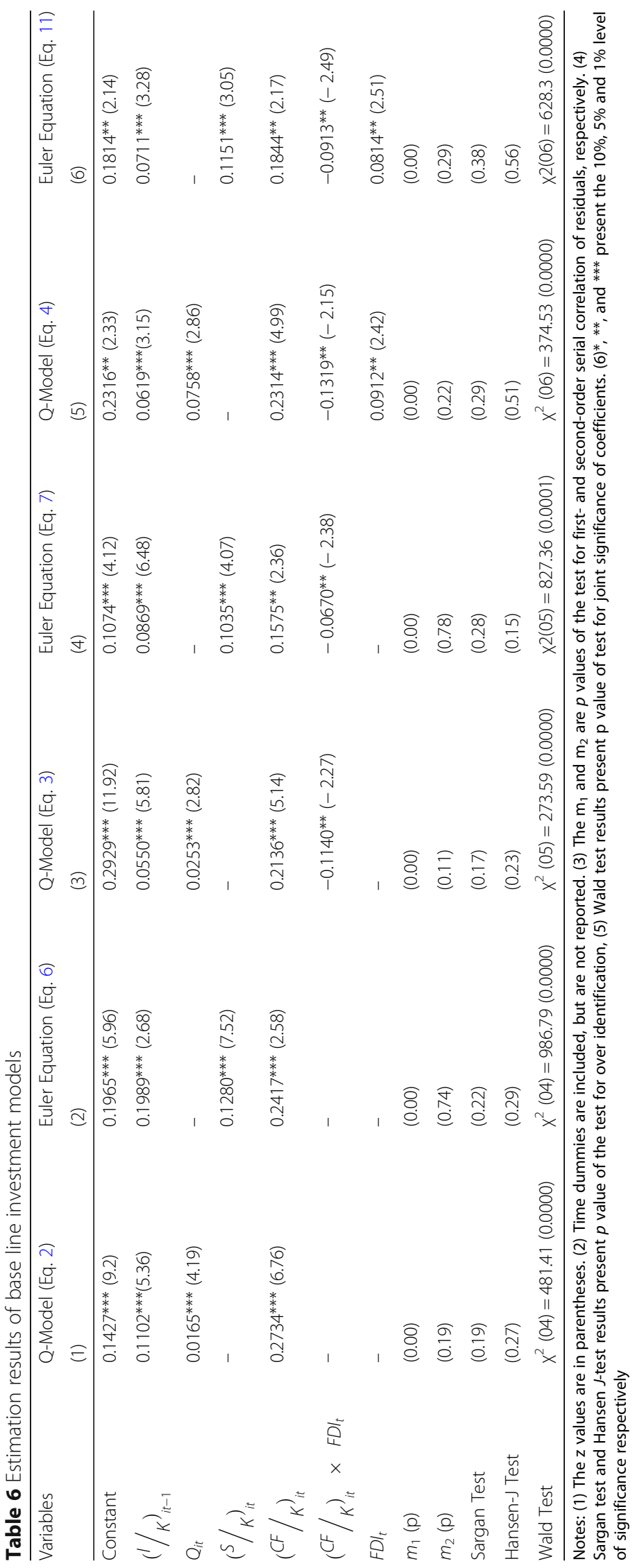


Columns (3) and (4) of the Table 6 present the results of the effect of financial development on cash flow-investment sensitivity (i.e. financial constraints). In both the investment models the interaction term of $F D I$ and $C F / K$ is included. Sargan test and Hansen $J$ test results indicate the validity of instrumental variables used in this model. The $m_{2}$ statistics rules out the existence of firm specific effects. Wald test results imply that the model is correctly specified. The regression coefficients of lagged investment to capital ratio, Tobin's Q, sales to capital ratio and cash flow have their expected sign and statistically significant. As an explanatory variable, the interaction term of cash flow and FDI is statistically significant having the negative coefficient for both the investment models suggest that financial development reduce financing constraints. This implies that the sensitivity of investment to cash flow decreases with the developments in the financial system. It could be due to the fact that financial development reduces the external borrowing constraints and thus, reduces the dependence of investment on internal funds. Columns (5) and (6) of the Table 6 present the results of the individual effect of financial development on corporate investment. Empirical results show that financial development is positively associated with corporate investment. All other variables have their sign as expected and are statistically significant. We also find similar results across industries within the manufacturing sector. ${ }^{6}$

The robustness of the results are tested across the different time periods and nature of the companies. Tables 7 and 8 present the results for before crisis period and during crisis period respectively. The first sub period is from 1999 to 2000 to 2006-07 (before crisis period), and the second sub period 2007-08 to 2013-14 (during crisis period), which has witnessed many financial crisis such as global financial crisis (2007), European sovereign debt crisis (2010) and Russian financial crisis (2014). It is assumed that due to the limited availability of funds in the crisis period the cost of external capital increases, which make the firms more financially constrained. In this context, we hypothesize that the impact of financial development on investment-cash flow sensitivity is more during the crisis period than the before crisis period. The $p$-value of $m_{2}$ test statistics, Sargan test and Hansen $J$ test results and Wald test results in Tables 7 and 8 suggest the little existence of firm specific effects, validity of the instruments and correct specification of model respectively. Results of Tables 7 and 8 reveal that investment-cash flow sensitivity is higher during the crisis period than before the crisis period. The results of interaction between cash flow and financial development dummy $C F /_{K} \times F D I$ explain that the financial development reduces the role of cash flow more in the crisis period than the before crisis. Also, the individual effect of financial development on corporate investment is more (less) during (before) the crisis period. All other variables have their sign as expected and are statistically significant.

\section{Robustness tests (time period and dividend tests)}

Tables 9 and 10 present the results for high dividend paying firms and low dividend paying firms respectively. The first sub sample is for firms which pay high dividend (greater than the mean dividend pay-out ratio), and the second sub sample for firms which pay low dividend (lesser than the mean dividend pay-out ratio period). Considering the study of Kaplan and Zingales (1997), it has been argued that high dividend paying 


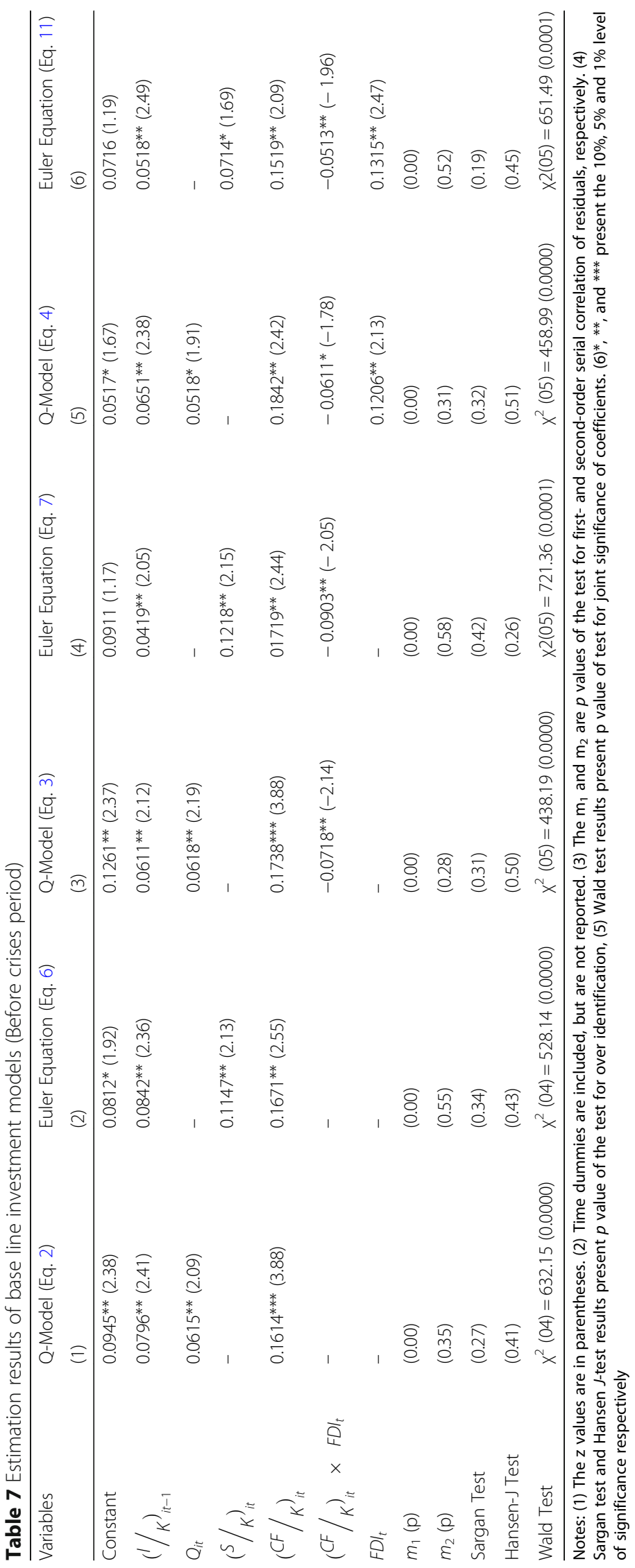




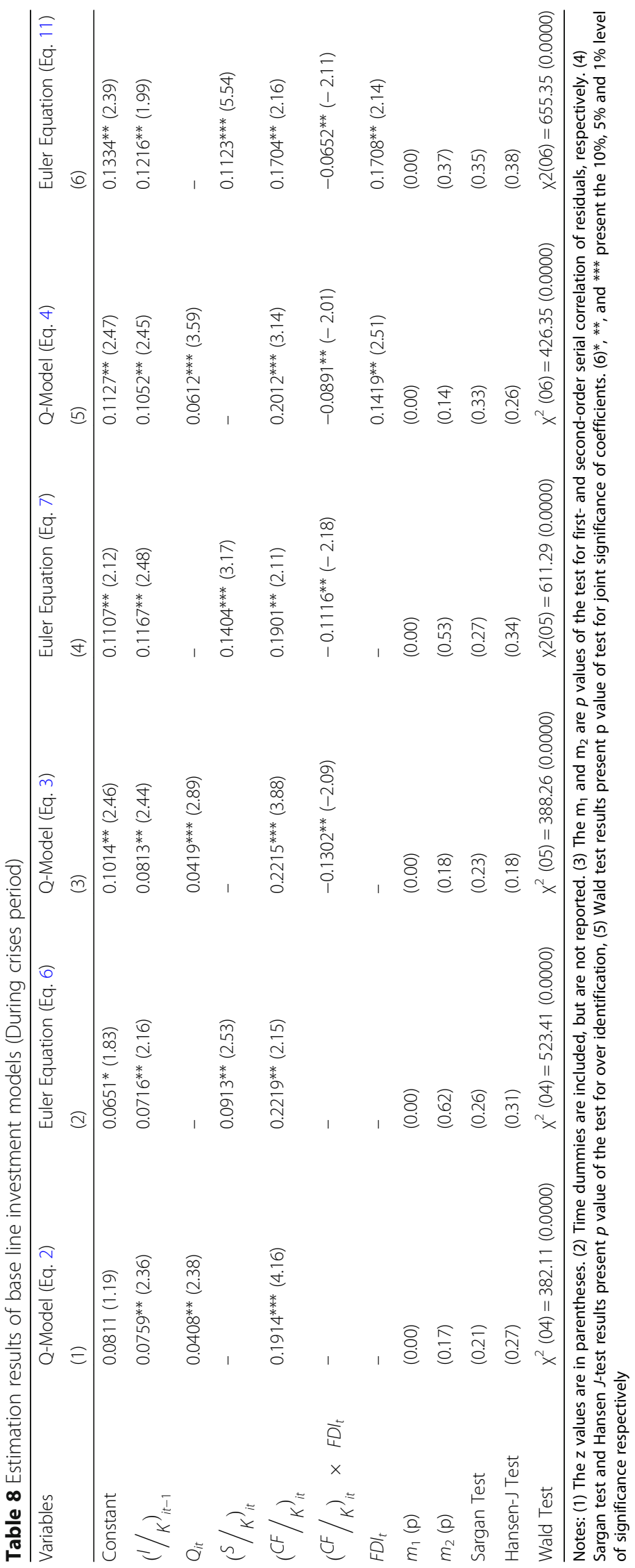




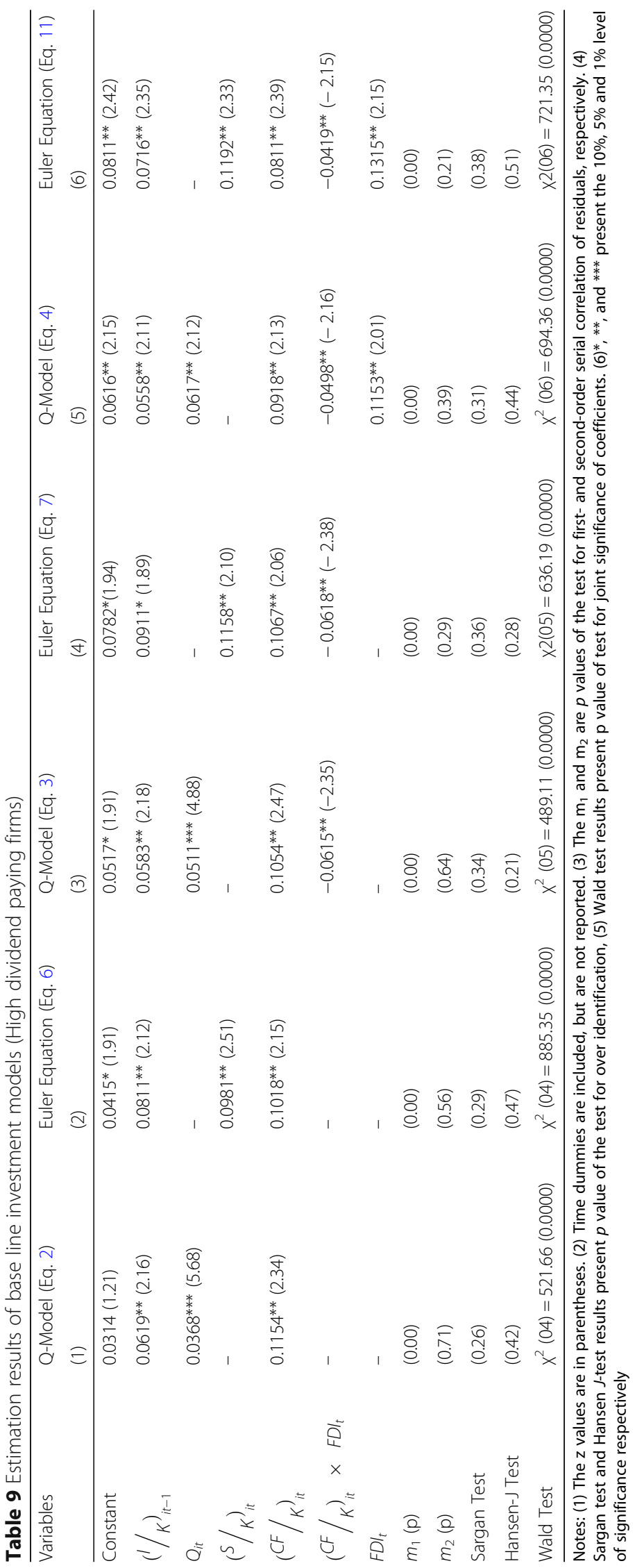




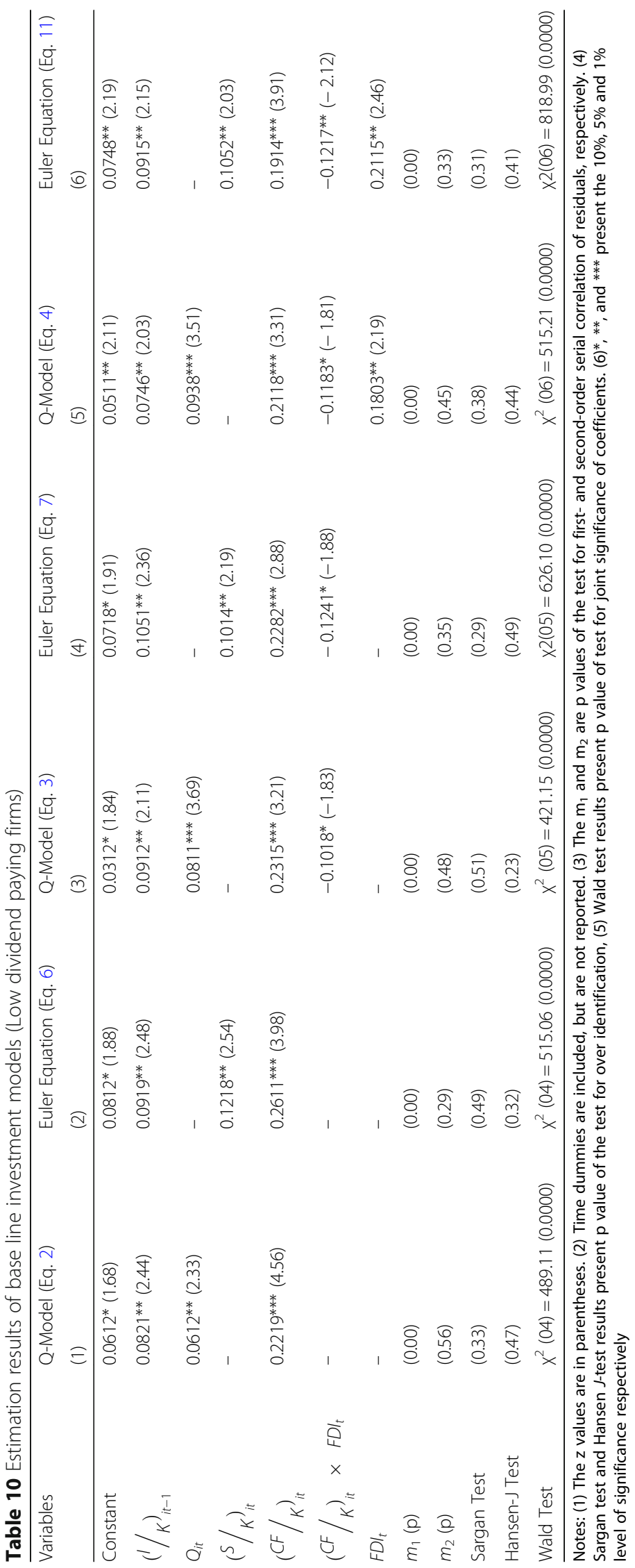


firms treated as non-financially constraints than those firms which pay less dividend and treated as financially constraints firms. Also, this study assumed that financially constraints (unconstraint) firms have high (low) investment cash flow sensitivity. Considering the effects of financial constraints, we hypothesize that financial development decreases more (less) the investment-cash flow sensitivity for the low (high) dividend paying firms. The $p$-value of $m_{2}$ test statistics, Sargan test and Hansen $J$ test results and Wald test results suggest the little existence of firm specific effects, validity of the instruments and correct specification of model respectively. We find that investment-cash flow sensitivity is high for the firms which pay low dividend than the firms which pay high dividend. The result of interactions between cash flow and financial development dummy $C F /{ }_{K} \times F D I$ reveal that financial development reduces the impact of cash flow on corporate investment more for low dividend paying firms that the high dividend paying firms, which can be infer form the coefficients of interaction of cash flow and financial development dummy presented in the Tables 9 and 10. Additionally, the independent role of financial development on corporate investment is more (less) for low (high) dividend paying firms. Also, all other variables have their sign as expected and are statistically significant.

\section{Effect heterogeneity (size and group tests)}

Further, we make an attempt to test whether financial development has any different impact on the investment-cash flow sensitivity across various firm characteristics. The columns (1) and (2) in Table 11 present the GMM estimation results of the investment models with the interaction terms between size of the company and financial development index. It is evident from the results that the sign of the coefficients of $C F /_{K} \times F D I \times B I G$ and $C F /_{K} \times F D I \times S M A L L$ are negative implying that the investment-cash flow sensitivity decreases with financial sector development. However, it is statistically significant in the case of SMALL and not for the BIG. This result suggests that small firms are more influenced by the financial development in India. Columns (3) and (4) of the Table 11 display the independent role of financial development on corporate investment. Empirical results reveal that financial development is positively associated with corporate investment across the size of the firms. All other estimates have their expected sign and the statistical significance. These results are consistent with the findings of Laeven (2003). The p-value of $m_{2}$ test statistics, Sargan test and Hansen $J$ test results and Wald test results suggest the little existence of firm specific effects, validity of the instruments and correct specification of model respectively.

Another subsample analysis is based on the affiliation of business group. STAND captures the independent, unaffiliated or standalone firms and GROUP represents the group affiliated firms. The results are presented in the columns (1) and (2) of the Table 12. All the test statistics supports the use of GMM estimation. Most of the previous studies claim that in India, independent or standalone firms are more financially constrained than the group affiliated firms (Khanna and Palepu 2000; Khanna and Palepu 1999a, 1999b; Khanna and Yafeh 2005). Group affiliated firms are generally not financially constraints due to the existence of internal capital market and it is easier for the affiliated firm to borrow from the external capital market because of their reputation and political connection (Lensink et al. 2003). 


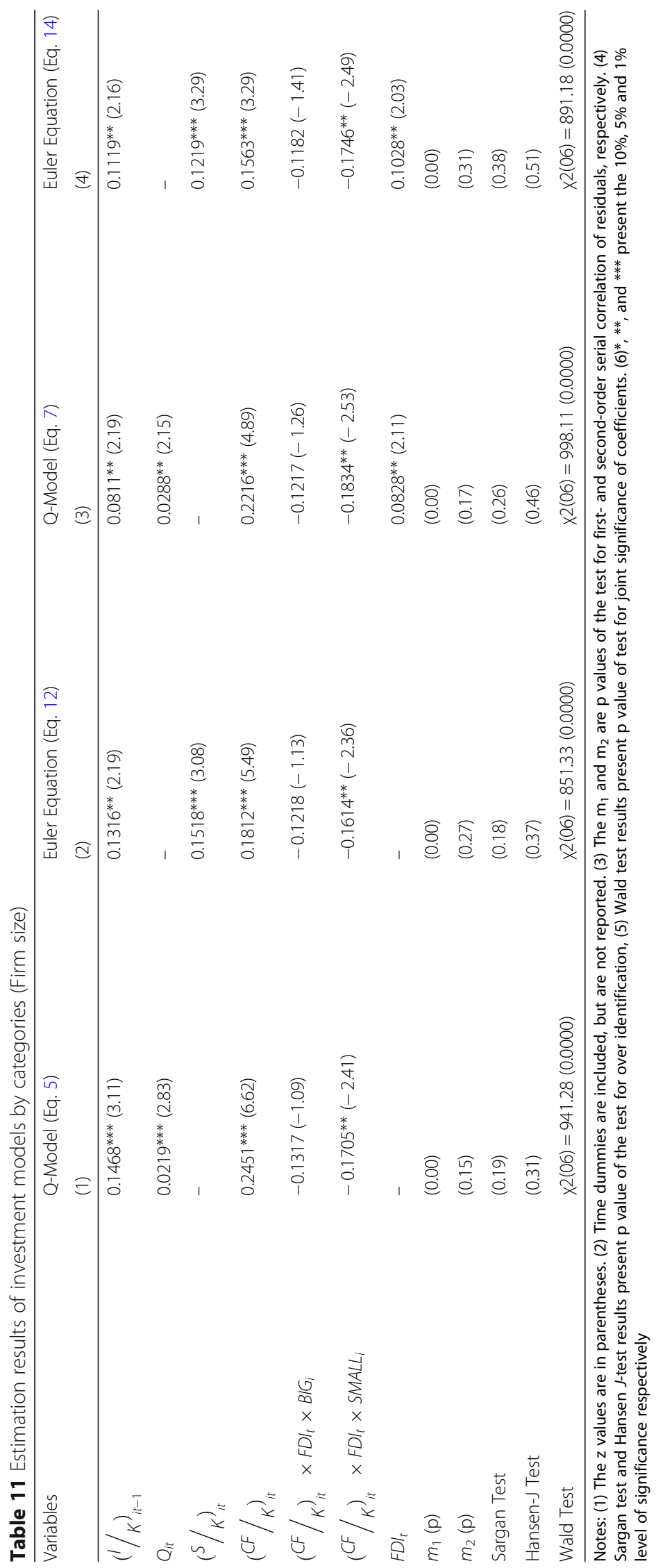




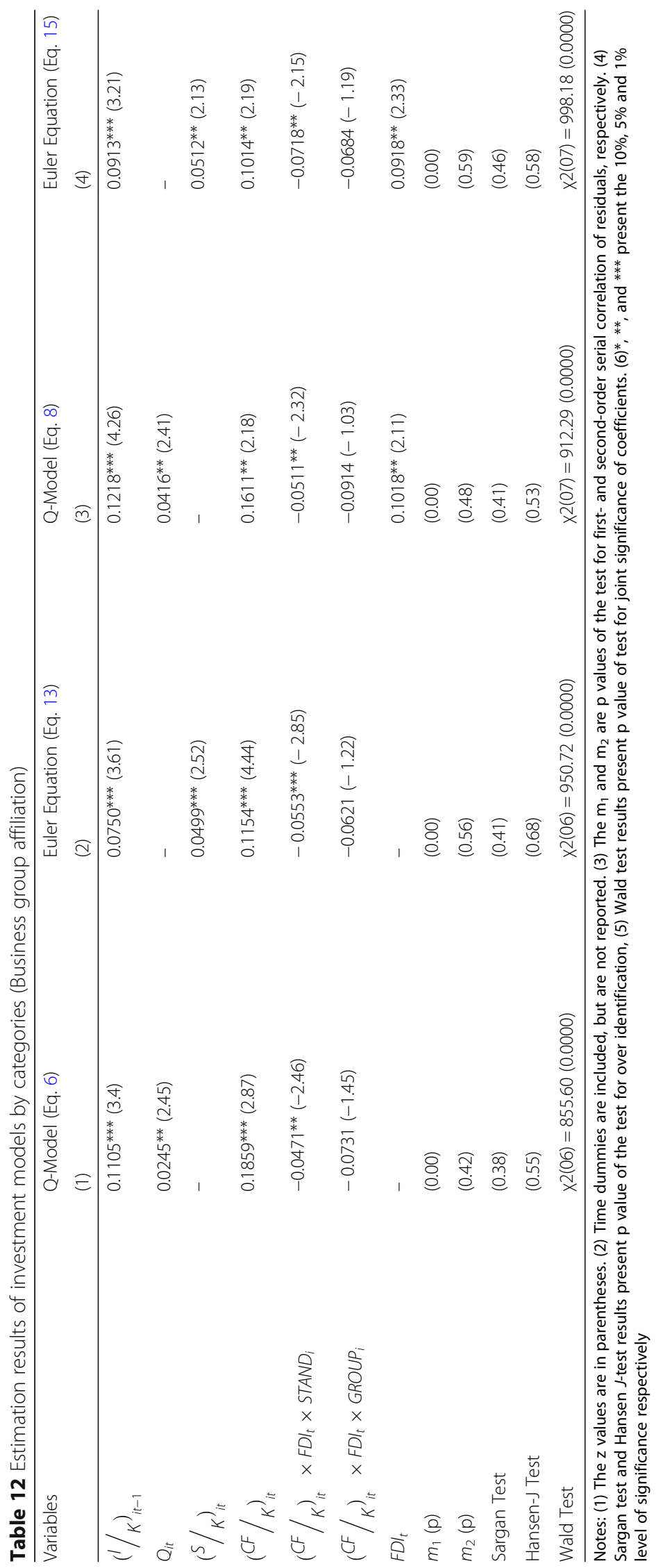


It is interesting to see the impact of financial development on the investment-cash flow sensitivity of group affiliated firms and standalone firms as it is expected that financial development, may reduce the financial constraint faced by the independent firms. The estimation results of the Q-model and Euler equation show that the regression coefficient in the interaction between financial development index and cash flow is more for group affiliated firms than the stand alone firms. However, the effect of development in financial sector on the investment-cash flow sensitivity of the group affiliated firms is not statistically significant, but for standalone firms, it is statistically significant at $5 \%$ level. This implies that standalone firms may have the better access to the external borrowings from the financial market due to the improvements in the financial market condition. Columns (3) and (4) of the Table 12 shows the independent role of financial development on corporate investment in both models. Empirical results postulate that financial development is positively associated with corporate investment across the ownership style of the firms. All other variables have their sign as expected and are statistically significant. These results are consistent with findings of Fazzari et al. (1988), La Cava (2005), Carpenter and Guariglia (2008), Guariglia (2008) and Chen and Chen (2012). In this study, we find strong evidence that financial development affects the financial constraints faced by the firms. We also find that the investment-cash flow sensitivity of the small and independent firms are seem to be significantly influenced more by financial development than the larger and group affiliated firms.

\section{Conclusions}

The empirical studies have mostly considered the impact of various exogenous factors like financial condition, liberalisation and corporate governance etc. on the investment-cash flow sensitivity. This study revisits the role of financial development on the role of internal liquidity in the determination of the investments undertaken by the firm in India. The empirical findings of this paper suggest that financial sector development decreases the role of internal cash flow in determining the investment undertaken by the firm. In other words, financial constraints measured by the cash flow sensitivity of investment, decreases with the financial development. This implies that development in the financial system increases the firms' availability to external borrowings and therefore, the reliance on internal cash flow for undertaking the investment declines. This study also reveals that the impact of financial development on the investment-cash flow sensitivity is more during the crisis period and low dividend paying firms than the before crisis period and high dividend paying firms. Further, this study also finds that small and non-affiliated firms, which are financially more constraints, seem to gain more from the financial sector development than the large and group affiliated firm. This study overall highlights the significance of financial development on determination of corporate investment in an emerging economy India.

\section{Endnotes}

${ }^{1}$ Debt ratios estimated as the ratio of total debt to capitalisation (sum of total debt and total shareholders' funds) and total debt to assets.

${ }^{2}$ Source: https://www.firstpost.com/blogs/when-it-comes-to-financial-sector-india-isway-ahead-of-china-1236293.html 
${ }^{3}$ Source: http://www.marketexpress.in/2017/01/india-other-emerging-markets-andhow-india-is-different.html

${ }^{4} V_{x}=\frac{x-x_{\min }}{x_{\max }-x_{\min }}, V_{x}=1-\frac{x-x_{\min }}{x_{\max }-x_{\min }}$ Here, $x$ is the underlying actual data and $\mathrm{V}$ is the transformed continues $0-1$ indicator.

${ }^{5}$ The data frequency is yearly, so that the number of observations is not adequate to employ the principal component analysis considering Indian data only. Therefore, we consider all the emerging economies data to construct the financial development index. We consider all the emerging countries, which have been commonly identified as emerging economy by International Monetary Fund (IMF), Morgan Stanley Capital International (MSCI), Standard and Poor's (S\&P), Russell and Dow Jones. This includes Brazil, Chile, China, Colombia, Hungary, Indonesia, India, Malaysia, Mexico, Peru, Philippines, Poland, Russia, South Africa, Thailand and Turkey.

${ }^{6}$ The sample comprises the data for 9 different industries. We have estimated both Q-model and Euler equation for each industry using the equation (1), (2), (3) and (4). As number of tables are many we have not presented all the results table here due to the lack of space. For brevity we have represented only whole sample results.

\section{Abbreviations}

CMIE: Centre for monitoring Indian economy; FDI: Financial development index; Fll: Foreign investment inflow; FOD: Forward orthogonal deviation; GDP: Gross domestic product; GMM: Generalized method of moments; IMF: International monetary fund; OECD: Organisation for economic co-operation and development; RBI: Reserve bank of India; VIF: Variance inflation factor

\section{Acknowledgments}

Not applicable.

\section{About the Authors'}

Gaurav Gupta is the Assistant Professor of Finance at the Business School of Vellore Institute of Technology, Vellore. He has pursued Ph.D. in the area of corporate investment from the Department of Humanities and Social Sciences, Indian Institute of Technology Kharagpur. His area of interest includes finance, economics and accounting.

Jitendra Mahakud is Professor of Economics and Finance at the Indian Institute of Technology, Kharagpur. His areas of research and teaching include financial market and institution, financial management, corporate finance, financial econometrics, macroeconomics, and monetary economics. He has published more than 40 papers in leading national and international journals and co-authored a book entitled Financial Institutions and Markets: Structure, Growth and Innovations published by McGraw-Hill Education.

Funding

There is no financial help to complete this particular research activity.

\section{Availability of data and materials}

The data is collected from the prowess database maintained by Center for Monitoring Indian Economy (CMIE) and World Bank Development Indicators.

Authors' contributions

All authors contributed to the success of the research work. Both authors read and approved the final manuscript.

Competing interests

The authors declare that they have no competing interests.

\section{Publisher's Note}

Springer Nature remains neutral with regard to jurisdictional claims in published maps and institutional affiliations.

\section{Author details}

${ }^{1}$ VIT Business School, Vellore Institute of Technology, Vellore 632014, India. ${ }^{2}$ Department of Humanities and Social

Sciences, Indian Institute of Technology Kharagpur, Kharagpur, West Bengal 721302, India. 
Received: 28 November 2017 Accepted: 27 December 2018

Published online: 09 January 2019

\section{References}

Ağca Ş, Mozumdar A (2008) The impact of capital market imperfections on investment-cash flow sensitivity. J Bank Financ 32(2):207-216

Aggarwal R, Zong S (2006) The cash flow-investment relationship: international evidence of limited access to external finance. J Multinatl Financ Manag 16(1):89-104

Ahn S, Denis DJ, Denis DK (2006) Leverage and investment in diversified firms. J Financ Econ 79(2):317-337

Aivazian VA, Ying G, Qui J (2005) The impact of leverage on firm investment: Canadian evidence. J Coro Financ 11(1):277-291

Allayannis G, Mozumdar A (2000) Investment, Cash Flow, and Hedging. New Orleans Meetings. Available at SSRN: https://ssrn. com/abstract=243639 or https://doi.org/10.2139/ssrn.243639

Allayannis G, Mozumdar A (2004) The impact of negative cash flow and influential observations on investment-cash flow sensitivity estimates. J Bank Financ 28(5):901-930

Alti A (2003) How sensitive is investment to cash flow when financing is frictionless? J Finance 58(2):707-722

Andrén N, Jankensgård H (2015) Wall of cash: the investment-cash flow sensitivity when capital becomes abundant. J Bank Financ 50:204-213

Arellano M, Bover O (1995) Another look at the instrumental variable estimation of error-components models. J Econom 68(1):29-51

Ascioglu A, Hegde SP, McDermott JB (2008) Information asymmetry and investment-cash flow sensitivity. J Bank Financ 32(6):1036-1048

Attig N, Cleary S, El Ghoul S, Guedhami O (2012) Institutional investment horizon and investment-cash flow sensitivity. J Bank Financ 36(4):1164-1180

Audretsch DB, Elston JA (2002) Does firm size matter? Evidence on the impact of liquidity constraints on firm investment behaviour in Germany. Int J Ind Organ 20(1):1-17

Bhaduri SN (2005) Investment, financial constraints and financial liberalization: some stylized facts from a developing economy, India. J Asian Econ 16(4):704-718

Blundell R, Bond S (1998) Initial conditions and moment restrictions in dynamic panel data models. J Econom 87(1):115-143

Brown JR, Petersen BC (2009) Why has the investment-cash flow sensitivity declined so sharply? Rising R\&D and equity market developments. J Bank Finance 33(5):971-984

Caggese A (2007) Testing financing constraints on firm investment using variable capital. J Financ Econ 86(3):683-723

Calomiris CW, Orphanides O, Sharpe SA (1994) Leverage as a state variable for employment, inventory accumulation, and fixed investment. In: Wood GE, Capie F (eds) Asset Prices and the Real Economy. Studies in Banking and International Finance, Palgrave Macmillan, London, pp 179-196

Carpenter RE, Guariglia A (2008) Cash flow, investment, and investment opportunities: new tests using UK panel data. J Bank Finance 32(9):1894-1906

Chauhan GS (2017) Corporate financing and deleveraging of firms in India. IIMB Management Review 29(3):170-187

Chen HJ, Chen SJ (2012) Investment-cash flow sensitivity cannot be a good measure of financial constraints: evidence from the time series. J Financ Econ 103(2):393-410

Chen YS, Chen IJ (2013) The impact of labor unions on investment-cash flow sensitivity. J Bank Financ 37(7):2408-2418

Chowdhury J, Kumar R, Shome D (2016) Investment-cash flow sensitivity under changing information asymmetry. J Bank Financ 62:28-40

Cleary S (1999) The relationship between firm investment and financial status. J Financ 54(2):673-692

Cleary S (2006) International corporate investment and the relationships between financial constraint measures. J Bank Financ 30(5):1559-1580

Cleary S, Povel P, Raith M (2007) The U-shaped investment curve: theory and evidence. J Financ Quant Anal 42(1):1-39

Degryse H, De Jong A (2006) Investment and internal finance: asymmetric information or managerial discretion? Int J Ind Organ 24(1):125-147

Devereux M, Schiantarelli F (1990) Investment, financial factors, and cash flow: Evidence from UK panel data. In: R, Glenn (ed) Asymmetric information, corporate finance, and investment, Natonal Bureao of Economc Research, University of Chicago Press: 279-306

Erickson T, Whited TM (2000) Measurement error and the relationship between investment and q. J Polit Econ 108(5):1027-1057

Fazzari SM, Hubbard RG, Petersen BC (2000) Investment-cash flow sensitivities are useful: a comment on Kaplan and Zingales. Quart J Econ 115(2):695-705

Fazzari SM, Hubbard RG, Peterson BC (1988) Financing constraints and corporate investment. Brookings Pap Econ Act 1988(1):141-206

Firth M, Malatesta PH, Xin Q, Xu L (2012) Corporate investment, government control, and financing channels: evidence from China's listed companies. J Corp Finance 18(3):433-450

Francis B, Hasan I, Song L, Waisman M (2013) Corporate governance and investment-cash flow sensitivity: evidence from emerging markets. Emerg Mark Rev 15:57-71

Froot KA, Scharfstein DS, Stein JC (1993) Risk management: coordinating corporate investment and financing policies. J Finance 48(5):1629-1658

Gatchev VA, Pulvino T, Tarhan V (2010) The interdependent and intertemporal nature of financial decisions: an application to cash flow sensitivities. J Finance 65(2):725-763

Geczy C, Minton BA, Schrand C (1997) Why firms use currency derivatives. J Finance 52(4):1323-1354

George R, Kabir R, Qian J (2011) Investment-cash flow sensitivity and financing constraints: new evidence from Indian business group firms. J Multinatl Financ Manag 21(2):69-88

Ghosh S, Ghosh S (2006) Impact of liquidity constraint on firms' investment decisions. Economia Internazionale 54(1):17-32

Gilchrist S, Himmelberg CP (1995) Evidence on the role of cash flow for investment. J Monetary Econ 36(3):541-572

Gochoco-Bautista MS, Sotocinal NR, Wang J (2014) Corporate investments in Asian markets: financial conditions, financial development, and financial constraints. World Dev 57(C):63-78 
Goergen M, Renneboog L (2001) Investment policy, internal financing and ownership concentration in the UK. J Corp Financ 7(3):257-284

Gomes JF (2001) Financing investment. Am Econ Rev 91(5):1263-1285

Guariglia A (2008) Internal financial constraints, external financial constraints, and investment choice: evidence from a panel of UK firms. J Bank Financ 32(9):1795-1809

Hatzius J, Hooper P, Mishkin F, Schoenholtz K, Watson M (2010) Financial conditions indexes: a fresh look after the financial crisis. NBER Working Papers No. 16150

Hoshi T, Kashyap A, Scharfstein D (1991) Corporate structure, liquidity, and investment: evidence from Japanese industrial groups. Q J Econ 106(1):33-60

Houston J, James C (1996) Bank information monopolies and the mix of private and public debt claims. J Financ 51(5):1863-1889

Islam SS, Mozumdar A (2007) Financial market development and the importance of internal cash: evidence from international data. J Bank Financ 31(3):641-658

Jangili R, Kumar S (2010) Determinants of private corporate sector investment in India. Reserve Bank India Occas Pap 31(3): 67-89

Jensen MC, Meckling WH (1976) Theory of the firm: managerial behavior, agency costs and ownership structure. J Financ Econ 3(4):305-360

Kadapakkam P, Kumar P, Riddick L (1998) The impact of cash flows and firm size on investment: the international evidence. J Bank Financ 22:293-320

Kaplan SN, Zingales L (1997) Do investment-cash flow sensitivities provide useful measures of financing constraints? Quart J Econ 112(1):169-215

Kaplan SN, Zingales L (2000) Investment-cash flow sensitivities are not valid measures of financing constraints. Quart J Econ 115(2):707-712

Kedia S, Mozumdar A (2001) Foreign currency denominated debt: an empirical examination. J Bus 76(4):521-564

Khanna T, Palepu K (1999a) The right way to restructure conglomerates in emerging markets. Harv Bus Rev 77(4):125-134

Khanna T, Palepu K (1999b) Policy shocks, market intermediaries, and corporate strategy: the evolution of business groups in Chile and India. J Econ Manag Strateg 8(2):271-310

Khanna T, Palepu K (2000) Is group membership profitable in emerging markets? An analysis of diversified Indian business groups. J Finance 55(2):867-891

Khanna T, Yafeh Y (2005) Business groups and risk sharing around the world. J Bus 78(1):301-340

King RG, Levine R (1993) Financial intermediation and economic development. Capital markets and financial intermediation, in Capital Markets and Financial Intermediation, Colin Mayer and Xavier Vives, eds. London: Cytre for Economic Policy Research 156-189

Koo J, Maeng K (2005) The effect of financial liberalization on firms' investments in Korea. J Asian Econo 16(2):281-297

La Cava G (2005) Financial constraints, the user cost of capital and corporate investment in Australia. Research Discussion Paper, Reserve Bank of Australia, UK

Laeven L (2003) Does financial liberalization reduce financing constraints? Financ Manag 32(1):5-34

Lamont O (1997) Cash flow and investment: evidence from internal capital markets. J Finance 52(1):83-109

Lensink R, Van der Molen R, Gangopadhyay S (2003) Business groups, financing constraints and investment: the case of India. J Dev Stud 40(2):93-119

Lin CH, Lin CH, Wang YY (2012) The impacts of firm size on the interactions between investment, financing and hedging decisions. J Stat Manag Syst 15(6):663-683

Loayza NV, Ranciere R (2006) Financial Development, Financial Fragility, and Growth. Journal of Money, Credit and Banking 38:1051-1076

Love I (2003) Financial development and financing constraints: international evidence from the structural investment model. Rev Financ Stud 16(3):765-791

Mitton (2007) Why Have Debt Ratio Increased of Firms in Emerging Markets. European Financial Management 14:127-151

Moshirian F, Nanda V, Vadilyev A, Zhang B (2017) What drives investment-cash flow sensitivity around the world? An asset tangibility perspective. J Bank Financ 77:1-17

Moyen N (2004) Investment-cash flow sensitivities: constrained versus unconstrained firms. J finance 59(5):2061-2092

Myers SC, Majluf NS (1984) Corporate financing and investment decisions when firms have information that investors do not have. J Financ Econ 13(2):187-221

Nickell SJ (1981) Biases in dynamic models with fixed effects. Econometrica 49(6):1417-1426

Pindado J, Requejo I, De La Torre C (2011) Family control and investment-cash flow sensitivity: empirical evidence from the euro zone. J Corp Finance 17(5):1389-1409

Ratti RA, Lee S, Seol Y (2008) Bank concentration and financial constraints on firm-level investment in Europe. J Bank Finance 32(12):2684-2694

Ro YJ, Kim IC, Kim JW (2017) Financial development and Investment in Korea. Emerg Mark Financ Trade 53(3):534-543

Schaller H (1993) Asymmetric information, liquidity constraints, and Canadian investment. Canadian J Econ 26(3):552-574

Shen CH, Wang CA (2005) Does bank relationship matter for a firm's investment and financial constraints? The case of Taiwan. Pac Basin Financ J 13(2):163-184

Shin H, Park Y (1999) Financing constraints and internal capital markets: evidence from Korean chaebols. J Corp Financ 5(2): 169-191

Singh M, Faircloth S (2005) The impact of corporate debt on long term investment and firm performance. Applied Economics 37(8):875-883

Svirydzenka K (2016) Introducing a new broad-based index of financial development. IMF working paper, working paper no. WP/16/5

Tran NH, Le CD (2017) Financial conditions and corporate investment: evidence from Vietnam. Pacific Account Rev 29(2):183-203

Whited TM, Erickson T (2002) Investment-Cash Flow Sensitivity and Proxy Quality Thresholds. https://ssrn.com/abstract= 354700. https://doi.org/10.2139/ssrn.354700. 